\title{
Foliar Application of Some Amino Acids and Vitamins to Improve Growth, Physical and Chemical Properties of Flame Seedless Grapevines
}

\author{
B.E.A. Belal, M.A. El-Kenawy and M.K. Uwakiem \\ Viticulture Department, Horticulture Research Institute, \\ Agricultural Research Centre, Cairo, Egypt.
}

\begin{abstract}
7 HIS STUDY was carried out during two successive seasons (2014 \& 2015) in a private vineyard at El-deer village, Aga, Dakahlia Governorate, Egypt. The experiment was conducted on 12year-old Flame seedless grapevines cultivar. The vines were grown in clay soil under surface irrigation system, trained to quadrilateral cordon using Gable supporting system. Three amino acids namely Methionine, Glutamic acid and Argenine at a rate (500 ppm) were used as a spray application either alone or with Vitamin B1 (Thiamin) or Vitamin B2 (Riboflavin) at a rate $(250 \mathrm{ppm})$ on the vines for three times at growth start (when shoots length reached about $40-50 \mathrm{~cm}$ ), after fruit set and 2 weeks after fruit set as an attempts to improve growth, physical and chemical properties of Flame seedless grapevines.
\end{abstract}

The Results showed that single applications of amino acids or in combination with vitamins B1 or B2 were effective in improving shoot length, leaf surface area, total chlorophyll and total amino acids in the leaves in addition percentages of $\mathrm{N}, \mathrm{P}, \mathrm{K}$ and $\mathrm{Mg}$ in the leaves as well as enhancing yield per vine, cluster weight, berry weight, soluble solids content, total sugars, total anthocyanin and total phenols while reducing total acidity in berries as compared with control in both seasons of study. In this respect, applications of amino acids plus vitamins were superior to using amino acids alone.

The best results with regard to vegetative growth, yield/vine, fruit quality and net profit of Flame seedless grapevines were obtained when vines were sprayed with Argenine plus vitamin B2.

Keywords: Grapevines, Flame seedless, Amino acids, Methionine, Glutamic acid, Argenine, Vitamins B1 and Vitamin B2.

Flame seedless grape is considered one of the most important grape cultivars grown in Egypt. This is basically due to it is high acceptance by both local consumers and exporters. Small sized berries and uneven colouration clusters one of the main draw backs that local growers of Delta. Overcoming these problems would lead to improve the market price for local consumption and exportation. 
Using amino acids not only increase growth but also enhance yield quality and quantity. The promoting affect of amino acids on protecting plant cells from oxidation and all stresses as well as enhancing the biosynthesis of proteins, plant pigments, natural hormones such as IAA, gibberellin and Ethylene and cell division is reflected on stimulating vine nutritional status and fruiting. Also, amino acids contain both acid and basic groups which act as buffers that help to maintain favorable $\mathrm{pH}$ value within the plant cell (Davies, 1982, Yagodin, 1990 and Rai, 2002).

Vitamins with their antioxidant properties play a vital role in plant defence against oxidative stresses induced by unfavorable conditions. Application of vitamins is accompanied with enhancing alpha keto glutaric acid biosynthesis which is united with ammonia to form amino acids and proteins, controlling the incidence of disorders and stimulating the biosynthesis of natural hormones like IAA, cytokinins and gibberellins, cell division, plant pigments, enzymes, organic foods and plant metabolism (Oretili, 1987 and Samiullah et al., 1988).

It was suggested that all vitamins participate in plant growth and development. Most studies showed that most of the essential physiological processes such as photosynthesis building of all organic foods and enzymes, building of plant pigments, nutrient and water uptake and cell division depended more or less on the availability of vitamins (Robinson, 1973).

The beneficial effects of amino acids and vitamins on growth, yield and quality of grapevines cvs. were emphasized by the findings of (Melouk, 2007, Megawer \& Abd El-Hameed 2009, Sabry Gehan, 2009, Fayed, 2010, Ahmed et al., 2011, Madian \& Refaai, 2011, Khan et al., 2012, El-Sayed, 2013, Abd-Elaal et al., 2014, Al-Khawaga 2014, Faissal et al., 2014 , Al-Wasfy, 2014 and Faissal et al., 2015).

The target of this study is to improve yield and quality of Flame seedless grapevines by using some amino acids and vitamins.

\section{Materials and Methods}

This investigation was carried out during two successive seasons (2014 \& 2015) in a private vineyard at El-deer village, Aga, Dakahlia Governorate, Egypt. The experiment was conducted on 12-year-old Flame seedless grapevines cultivar. Vines were cultivated at $1.5 \times 3 \mathrm{~m}$. in a clay soil as shown in Table 1 under surface irrigation system from Nile water. Vines were trained to quadrilateral cordon using Gable supporting system. During January of each experimental season, the tested vines were spur- pruned by leaving 6 spurs with 2 eyes on each cordon. The total bud load was 48 buds. Ninety vines uniform in vigor as possible were chosen for this study, all vines received the same cultural management recommended by ministry of agriculture. The experiment consisted of ten treatments arranged in a complete randomize blocks design, each treatment include three replicates, each made of three vines.

Egypt. J. Hort. Vol. 43, No. 1 (2016) 
TABLE 1. Mechanical and chemical analysis of the experimental soil.

\begin{tabular}{|l|l|l|}
\hline \multirow{4}{*}{ Mechanical } & Clay (\%) & 48.15 \\
\cline { 2 - 3 } & Silt (\%) & 24.69 \\
\cline { 2 - 3 } & Sand (\%) & 27.16 \\
\cline { 2 - 3 } & Texture & Clay \\
\hline \multirow{5}{*}{ Chemical } & O.M. (\%) & 2.1 \\
\cline { 2 - 3 } & $\mathrm{pH}(1: 25)$ & 7.8 \\
\cline { 2 - 3 } & E.C.( $1: 5$ extract) (Mmhos/cm) & 0.62 \\
\cline { 2 - 3 } & $\mathrm{Ca} \mathrm{Co}(\%)$ & 1.88 \\
\cline { 2 - 3 } & $\mathrm{N}(\mathrm{ppm})$ & 38 \\
\cline { 2 - 3 } & $\mathrm{P}(\mathrm{ppm})$ & 11 \\
\cline { 2 - 3 } & $\mathrm{K}(\mathrm{ppm})$ & 282 \\
\hline
\end{tabular}

Three amino acids i.e. Methionine $\left(\mathrm{C}_{5} \mathrm{H}_{11} \mathrm{NO}_{2} \mathrm{~S}\right)$, Glutamic acid $\left(\mathrm{C}_{5} \mathrm{H}_{9} \mathrm{NO}_{4}\right)$ and Argenine $\left(\mathrm{C}_{6} \mathrm{H}_{14} \mathrm{~N}_{4} \mathrm{O}_{2}\right)$ were foliar applied at a rate $(500 \mathrm{ppm})$ with or without Vitamin B1 (Thiamin) or Vitamin B2 (Riboflavin) at a rate of (250 $\mathrm{ppm}$ ) on the vines for three times, at growth start (when shoots length reached about $40-50 \mathrm{~cm}$ ), after fruit set and 2 weeks after fruit set. Treatments applied as follow:

- Control

- Methionine

- Methionine + vitamin B1

- Methionine + vitamin B2

- Glutamic Acid

- Glutamic Acid + vitamin B1

- Glutamic Acid + vitamin B2

- Argenine

- Argenine + vitamin B1

- Argenine + vitamin B2

\section{Measurements}

Vegetative growth parameters (shoot length and leaf surface area)

Vegetative growth parameters were determined after two weeks from last treatment (one month after fruit set) from non-fruiting shoots as follows:

- Average shoots length $(\mathrm{cm})$.

- Average leaf area $\left(\mathrm{cm}^{2}\right)$ : Sixth and seventh leaves from the tip of the growing shoot were used for leaf surface area measurement according to (Montero et al., 2000).

Chlorophyll content in the leaves

Sixth and seventh leaves from the tip of the growing shoots were used for the determination of total chlorophyll content in the leaves after two weeks from last treatment according to (Mackinny, 1941) total chlorophyll was calculated as (mg/g fresh weight). 


\section{$N, P, K, M g$ and total amino acids content in the leaves}

After two weeks from last treatment, samples of 20 leaf petioles per each replicate were taken from leaves opposite to cluster and used for the determination of $\mathrm{N}, \mathrm{P}, \mathrm{K}$ and $\mathrm{Mg}$ content according to (Cottenie et al., 1982). The blades of leaves were used for the determination of total free amino acids as (g /100g dry weight) according to (Selim et al., 1978).

\section{Yield}

At harvesting time when SSC \% of berries reached about 16-17\% in control, six clusters/ vine were weighted and the average cluster weight was multiplied by number of clusters /vine to calculation average yield / vine.

\section{Physical and chemical properties}

A sample of 6 clusters /vine was taken to determine:

- Average cluster weight (g) and average of 100 berry weight (g)

- Soluble solids content (SSC \%) was determined by using hand refractometer.

- Total acidity percentage was determined according to (A.O.A.C. 1980).

- Total sugars (\%) were determined according to (Sadasivam and Manickam, 1996).

- Total anthocyanin content of the berries skin (mg/100g F.W) was calculated according to (Husia et al., 1965).

- Total phenols in the berries (mg/100g D.W) were determined according to (Malick and Singh, 1980).

\section{Statistical Analysis}

The complete randomized blocks design was adopted for the experiment. The statistical analysis of the present data was carried out according to (Snedecor and Chocran, 1980). Averages were compared using the new L.S.D. values at $5 \%$ level.

\section{Results}

Shoot length, leaf surface area, total chlorophyll and total amino acids

It is clear from the obtained data in Table 2 that treating the vines with amino acids namely Methionine and Argenine without or with vitamin B1 or vitamin B2 significantly enhanced shoot length, leaf area, total chlorophyll and total amino acids in the leaves as compared with control. Non-significantly differences between Methionine (T2) and Argenine (T8) were clear in this respect. Also, the data showed non-significantly differences between Glutamic (T5) and control (T1) on shoot length and total chlorophyll in both seasons of study. The highest values were recorded when the vines were spraying Argenine plus vitamin B2 (T10) which recorded $(188.0$ and $188.3 \mathrm{~cm}$ ) for shoot length, (192 and $197.3 \mathrm{~cm}^{2}$ ) for leaf area, (17.04 and $16.81 \mathrm{mg} / \mathrm{g} \mathrm{F.W.)} \mathrm{for} \mathrm{total}$ chlorophyll, and (1.32 and 1.44 g /100g D.W.) for total amino acids in 2014 and 2015 seasons, respectively as compared with other treatments.

Egypt. J. Hort. Vol. 43, No. 1 (2016) 
TABLE 2. Effect of some amino acids and vitamins application on shoot length, leaf area, total chlorophyll and total amino acids in Flame seedless grapevines during 2014 and 2015 seasons

\begin{tabular}{|l|l|l|l|l|l|l|l|l|l|}
\hline \multicolumn{2}{|c}{ Treatments } & \multicolumn{2}{|c|}{$\begin{array}{c}\text { Shoot length } \\
(\mathbf{c m})\end{array}$} & \multicolumn{2}{c|}{$\begin{array}{c}\text { Leaf area } \\
\left(\mathbf{c m}^{2}\right)\end{array}$} & \multicolumn{2}{c|}{$\begin{array}{c}\text { Total } \\
\text { chlorophyll } \\
(\mathbf{m g} / \mathbf{g} \text { F.W })\end{array}$} & \multicolumn{2}{c|}{$\begin{array}{c}\text { Total amino } \\
\text { acids } \\
(\mathbf{g} / \mathbf{1 0 0 g} \text { D.W })\end{array}$} \\
\cline { 2 - 10 } & $\mathbf{2 0 1 4}$ & $\mathbf{2 0 1 5}$ & $\mathbf{2 0 1 4}$ & $\mathbf{2 0 1 5}$ & $\mathbf{2 0 1 4}$ & $\mathbf{2 0 1 5}$ & $\mathbf{2 0 1 4}$ & $\mathbf{2 0 1 5}$ \\
\hline 1 & Control & 157.7 & 160.3 & 163.3 & 165.0 & 13.80 & 14.13 & 0.96 & 1.01 \\
\hline 2 & Methionine & 172.7 & 171.6 & 177.3 & 178.0 & 14.92 & 15.18 & 1.14 & 1.22 \\
\hline 3 & $\begin{array}{l}\text { Methionine + } \\
\text { vitamin B1 }\end{array}$ & 178.0 & 179.0 & 185.7 & 185.7 & 15.32 & 15.68 & 1.23 & 1.35 \\
\hline 4 & $\begin{array}{l}\text { Methionine }+ \\
\text { vitamin B2 }\end{array}$ & 185.0 & 187.0 & 194.0 & 190.0 & 16.11 & 16.34 & 1.28 & 1.42 \\
\hline 5 & $\begin{array}{l}\text { Glutamic } \\
\text { Acid }\end{array}$ & 165.0 & 168.3 & 172.0 & 173.0 & 14.14 & 14.53 & 1.12 & 1.20 \\
\hline 6 & $\begin{array}{l}\text { Glutamic } \\
\text { Acid+ }\end{array}$ & 175.0 & 179.7 & 182.7 & 182.0 & 15.04 & 15.35 & 1.20 & 1.31 \\
\hline 7 & $\begin{array}{l}\text { Glutamic } \\
\text { Acid + }\end{array}$ & 183.0 & 177.0 & 185.7 & 188.0 & 15.85 & 15.94 & 1.26 & 1.387 \\
\hline 8 & Argenine & 170.0 & 173.3 & 179.0 & 182.0 & 15.30 & 15.58 & 1.17 & 1.25 \\
\hline 9 & $\begin{array}{l}\text { Argenine + } \\
\text { vitamin B1 }\end{array}$ & 180.0 & 185.0 & 187.7 & 192.7 & 16.68 & 16.32 & 1.26 & 1.38 \\
\hline 10 & $\begin{array}{l}\text { Argenine + } \\
\text { vitamin B2 }\end{array}$ & 188.0 & 188.3 & 192 & 197.3 & 17.04 & 16.81 & 1.32 & 1.44 \\
\hline New L.S.D at 5\% & 7.8 & 8.2 & 5.6 & 7.8 & 0.40 & 0.42 & 0.04 & 0.04 \\
\hline
\end{tabular}

$N, P, K$ and $M g(\%)$ content in leaf petioles

The concerned data in Table 3 showed that spraying grapevines with amino acids either alone or with vitamin B1 or vitamin B2 increased the nutrients content as it gave the highest values of $\mathrm{N}, \mathrm{P}, \mathrm{K}$ and $\mathrm{Mg}$ content in leaf petioles compared with control. The results also indicated that the differences between the values of Glutamic acid (T5) and control (T1) was insignificant of P \% and $\mathrm{Mg} \%$ in leaf petioles during both seasons of study. Also, the data showed that the treatment of Argenine + vitamin B2 (T10) recorded pronounced significant values in $\mathrm{N}, \mathrm{P}, \mathrm{K}$ and $\mathrm{Mg}$ content in leaf petioles. The $\mathrm{N}$ values were (2.54 and $2.62 \%)$, the $\mathrm{P}$ values were $(0.32$ and $0.35 \%)$, the $\mathrm{K}$ values were (1.85 and 1.85 $\%$ ) and the $\mathrm{Mg}$ values were (0.80 and 0.78\%) during 2014 and 2015 seasons, respectively. While the lowest values in this respect were recorded by control (T1) which recorded values of (1.77 and 1.84), (0.18 and 0.20), (1.42 and 1.38) and $(0.44$ and 0.47$)$ in $\mathrm{N}, \mathrm{P}, \mathrm{K}$ and $\mathrm{Mg}$ content in leaf petioles, respectively, in both seasons of study. 
TABLE 3. Effect of some amino acids and vitamins application on percentages of $\mathrm{N}$, $\mathrm{P}, \mathrm{K}$ and $\mathrm{Mg}$ in Flame seedless grapevines during 2014 and 2015 seasons

\begin{tabular}{|c|c|c|c|c|c|c|c|c|c|}
\hline \multirow{2}{*}{\multicolumn{2}{|c|}{ Treatments }} & \multicolumn{2}{|c|}{ Leaf N (\%) } & \multicolumn{2}{|c|}{ Leaf P (\%) } & \multicolumn{2}{|c|}{ Leaf K (\%) } & \multicolumn{2}{|c|}{ Leaf Mg (\%) } \\
\hline & & 2014 & 2015 & 2014 & 2014 & 2014 & 2015 & 2014 & 2015 \\
\hline 1 & Control & 1.77 & 1.84 & 0.18 & 0.20 & 1.42 & 1.38 & 0.44 & 0.47 \\
\hline 2 & Methionine & 2.15 & 2.28 & 0.24 & 0.26 & 1.62 & 1.66 & 0.58 & 0.62 \\
\hline 3 & $\begin{array}{l}\text { Methionine + } \\
\text { vitamin B1 }\end{array}$ & 2.34 & 2.45 & 0.27 & 0.32 & 1.75 & 1.77 & 0.70 & 0.72 \\
\hline 4 & $\begin{array}{l}\text { Methionine + } \\
\text { vitamin B2 }\end{array}$ & 2.46 & 2.58 & 0.29 & 0.35 & 1.82 & 1.85 & 0.78 & 0.78 \\
\hline 5 & Glutamic Acid & 1.97 & 2.11 & 0.22 & 0.22 & 1.55 & 1.6 & 0.52 & 0.54 \\
\hline 6 & $\begin{array}{l}\text { Glutamic Acid+ } \\
\text { vitamin B1 }\end{array}$ & 2.28 & 2.35 & 0.26 & 0.28 & 1.67 & 1.74 & 0.66 & 0.68 \\
\hline 7 & $\begin{array}{l}\text { Glutamic Acid } \\
\text { + vitamin B2 }\end{array}$ & 2.39 & 2.48 & 0.26 & 0.32 & 1.8 & 1.8 & 0.73 & 0.72 \\
\hline 8 & Argenine & 2.22 & 2.28 & 0.24 & 0.27 & 1.72 & 1.7 & 0.64 & 0.65 \\
\hline 9 & $\begin{array}{l}\text { Argenine + } \\
\text { vitamin B1 }\end{array}$ & 2.42 & 2.51 & 0.28 & 0.34 & 1.8 & 1.82 & 0.74 & 0.75 \\
\hline 10 & $\begin{array}{l}\text { Argenine + } \\
\text { vitamin B2 }\end{array}$ & 2.54 & 2.62 & 0.32 & 0.35 & 1.85 & 1.85 & 0.8 & 0.78 \\
\hline \multicolumn{2}{|c|}{ New L.S.D at $5 \%$} & 0.16 & 0.21 & 0.05 & 0.06 & 0.10 & 0.11 & 0.10 & 0.10 \\
\hline
\end{tabular}

Yield, cluster weight and 100 berry weight

Data in Table 4 clearly indicated that spraying Flame seedless grapevines three times with Methionine, Glutamic acid and Argenine either single or combination with vitamin B1 or vitamin B2 significantly increased yield per vine, cluster weight and 100 berry weight as compared with control during both seasons. The combinations of amino acids plus vitamin B1 or vitamin B2 were favorable than using amino acids alone in this respect. The treatment of Argenine + vitamin B2 (T10) recorded the best significant values in yield per vine (12.72 and $13.15 \mathrm{~kg} /$ vine $)$, cluster weight (570 and $588 \mathrm{~g} / \mathrm{vine}$ ) and 100 berry weight (293 and $296 \mathrm{~g} / \mathrm{vine}$ ) in 2014 and 2015 seasons, respectively. While the control treatment (T1) gave the lowest values in this respect (10.90 and $11.25 \mathrm{~kg} / \mathrm{vine}$ ) as for yield per vine, (437 and $442 \mathrm{~g} / \mathrm{vine}$ ) for cluster weight and (224 and 232 g/vine) for 100 berry weight in 2014 and 2015 seasons, respectively.

Egypt. J. Hort. Vol. 43, No. 1 (2016) 
TABLE 4. Effect of some amino acids and vitamins application on yield/vine, cluster weight and 100 berry weights in Flame seedless grapevines during 2014 and 2015 seasons.

\begin{tabular}{|l|l|c|c|c|c|c|c|}
\hline \multirow{2}{*}{ Treatments } & \multicolumn{2}{|c|}{$\begin{array}{c}\text { Yield/vine } \\
\text { (Kg) }\end{array}$} & \multicolumn{2}{c|}{$\begin{array}{c}\text { Cluster weight } \\
\text { (g) }\end{array}$} & \multicolumn{2}{c|}{$\begin{array}{c}\text { berry weight } \\
\text { (g) }\end{array}$} \\
\cline { 2 - 8 } & $\mathbf{2 0 1 4}$ & $\mathbf{2 0 1 5}$ & $\mathbf{2 0 1 4}$ & $\mathbf{2 0 1 5}$ & $\mathbf{2 0 1 4}$ & $\mathbf{2 0 1 5}$ \\
\hline 1 & Control & 10.90 & 11.25 & 437 & 442 & 224 & 232 \\
\hline 2 & Methionine & 11.51 & 11.4 & 480 & 482 & 265 & 270 \\
\hline 3 & $\begin{array}{l}\text { Methionine + } \\
\text { vitamin B1 }\end{array}$ & 11.94 & 12.76 & 498 & 532 & 275 & 285 \\
\hline 4 & $\begin{array}{l}\text { Methionine + } \\
\text { vitamin B2 }\end{array}$ & 12.35 & 13.04 & 538 & 572 & 286 & 292 \\
\hline 5 & Glutamic Acid & 11.40 & 11.37 & 467 & 475 & 254 & 258 \\
\hline 6 & $\begin{array}{l}\text { Glutamic Acid+ } \\
\text { vitamin B1 }\end{array}$ & 11.68 & 12.09 & 487 & 518 & 274 & 279 \\
\hline 7 & $\begin{array}{l}\text { Glutamic Acid + } \\
\text { vitamin B2 }\end{array}$ & 12.24 & 12.94 & 503 & 547 & 282 & 289 \\
\hline 8 & Argenine & 11.69 & 11.64 & 487 & 490 & 272 & 280 \\
\hline 9 & $\begin{array}{l}\text { Argenine + } \\
\text { vitamin B1 }\end{array}$ & 12.06 & 12.75 & 510 & 554 & 280 & 290 \\
\hline 10 & $\begin{array}{l}\text { Argenine + } \\
\text { vitamin B2 }\end{array}$ & 12.72 & 13.15 & 570 & 588 & 293 & 296 \\
\hline New L.S.D at 5\% & 0.15 & 0.10 & 20 & 21 & 29 & 24 \\
\hline
\end{tabular}

Chemical characteristics of the berries

Data in Table 5 clearly showed that all treatments used significantly increased soluble solids content $\%$, total sugars $\%$, total anthocyanin and total phenols while these reduced total acidity $\%$ in berries as compared with control except Glutamic acid treatment (T5) gave a non significantly differences in SSC $\%$ and total acidity $\%$ as compared with control in both seasons of study. Using amino acids in combination with vitamins were more favorable than using amino acids alone in this respect. The results also indicated that the difference between the treatment of Methionine + vitamin B2 (T4) and Argenine + vitamin B2 (T10) of soluble solids content, total sugars, total anthocyanin and total acidity were insignificant.

The treatment of Methionine + vitamin B2 (T4) gave in both seasons not only the highest values in soluble solids content (19.2 and $18.8 \%$ ), total sugars (16.76 and $16.59 \%$ ) and total anthocyanin (36.70 and $37.22 \mathrm{mg} / 100 \mathrm{~g}$ F.W) but also the lowest total acidity (0.513 and $0.527 \%)$ in 2014 and 2015 seasons, respectively, as compared with other treatments. Furthermore the treatment of Argenine + vitamin B2 (T10) recorded pronounced significant values in total phenols (109.83 and107.33 mg/100g D.W) in 2014 and 2015 seasons, respectively, as compared with other treatments. 


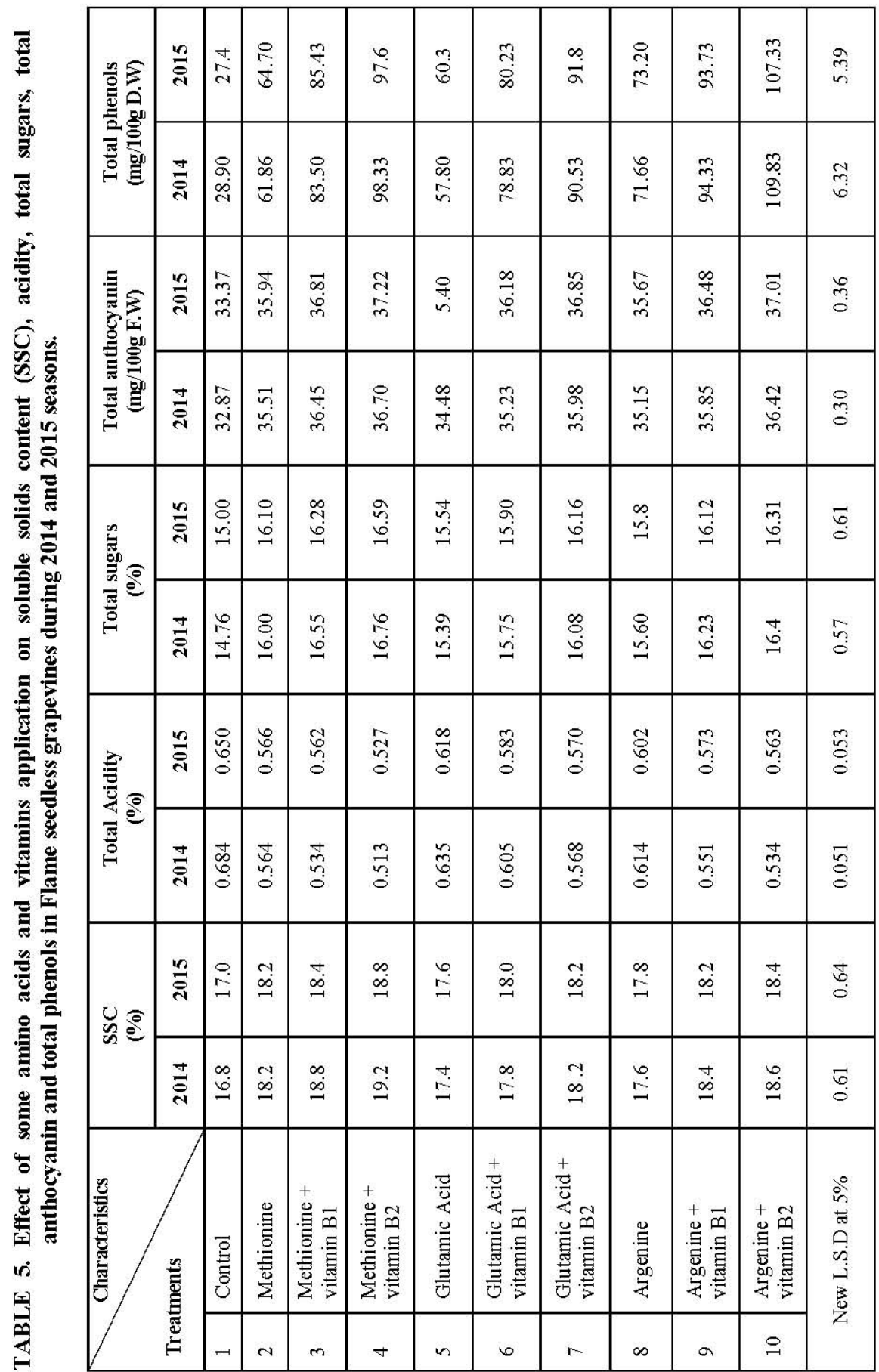

Egypt. J. Hort. Vol. 43, No. 1 (2016) 
The economic study

It is clear from the obtained data in Table 6 that spraying amino acids i.e. Methionine, Glutamic acid and Argenine either alone or combination with vitamin B1 or vitamin B2 gave the best net profit /feddan as compared with control. Also, the combination of amino acids plus vitamin B2 gave the highest net profit /feddan compared with amino acids plus vitamin B1 or amino acids alone. In addition, the treatment of Argenine + vitamin B2 gave the highest values in net profit /feddan which recorded 3580 (L. E.) over control as average two seasons.

TABLE 6. Economic study on costs and net profit /feddan of some amino acids and vitamins applications of Flame seedless as average for two seasons (2014 and 2015).

\begin{tabular}{|c|c|c|c|c|c|c|c|c|}
\hline \multicolumn{2}{|c|}{ Treatments } & $\begin{array}{l}\text { Costs of } \\
\text { cultural } \\
\text { practices/ } \\
\text { fed. (L.E.) }\end{array}$ & $\begin{array}{l}\text { Treatments } \\
\text { costs/fed. } \\
\text { (L.E.) }\end{array}$ & $\begin{array}{c}\text { Total } \\
\text { costs / } \\
\text { fed. } \\
\text { (L.E.) }\end{array}$ & $\begin{array}{l}\text { Yield/ } \\
\text { fed. } \mathrm{Kg}\end{array}$ & $\begin{array}{c}\text { Total } \\
\text { production } \\
\text { /fed. } \\
\text { (L.E.) }\end{array}$ & $\begin{array}{l}\text { Net } \\
\text { profit } \\
\text { / fed. } \\
\text { (L.E.) }\end{array}$ & $\begin{array}{c}\text { Net profit } \\
\text { /fed. over } \\
\text { control } \\
\text { (L.E.) }\end{array}$ \\
\hline 1 & Control & 6200 & 0 & 6200 & 9968 & 24920 & 18720 & 0 \\
\hline 2 & Methionine & 6200 & 30 & 6230 & 10310 & 25775 & 19545 & 825 \\
\hline 3 & $\begin{array}{l}\text { Methionine + } \\
\text { vitamin B1 }\end{array}$ & 6200 & 500 & 6700 & 11115 & 27788 & 21088 & 2368 \\
\hline 4 & $\begin{array}{l}\text { Methionine + } \\
\text { vitamin B2 }\end{array}$ & 6200 & 480 & 6680 & 11425 & 28563 & 21883 & 3163 \\
\hline 5 & $\begin{array}{l}\text { Glutamic } \\
\text { Acid }\end{array}$ & 6200 & 20 & 6220 & 10246 & 25615 & 19395 & 675 \\
\hline 6 & $\begin{array}{l}\text { Glutamic Acid+ } \\
\text { vitamin B1 }\end{array}$ & 6200 & 490 & 6690 & 10697 & 26743 & 20053 & 1333 \\
\hline 7 & $\begin{array}{l}\text { Glutamic Acid + } \\
\text { vitamin B2 }\end{array}$ & 6200 & 470 & 6670 & 11331 & 28327 & 21657 & 2937 \\
\hline 8 & Argenine & 6200 & 150 & 6350 & 10498 & 26245 & 19895 & 1175 \\
\hline 9 & $\begin{array}{l}\text { Argenine + } \\
\text { vitamin B1 }\end{array}$ & 6200 & 620 & 6820 & 11164 & 27910 & 21090 & 2370 \\
\hline 10 & $\begin{array}{l}\text { Argenine + } \\
\text { vitamin B2 }\end{array}$ & 6200 & 600 & 6800 & 11640 & 29100 & 22300 & 3580 \\
\hline
\end{tabular}

* Cultural practices such as (Fertilizers, Pesticides, fungicides, Irrigation and Labour)

- Methionine (g) $150 \times 3$ doses $=450 \mathrm{~g}=30$ (L.E.) $/$ feddan

- Glutamic Acid (g) $150 \times 3$ doses $=450 \mathrm{~g}=20$ (L.E.) $/$ feddan

- Argenine (g) $150 \times 3$ doses $=450 \mathrm{~g}=150$ (L.E.) $/$ feddan

- Vitamin B1 (g) $75 \times$ 3doses $=225 \mathrm{~g}=470$ (L.E.) $/$ feddan

- Vitamin B2 (g) $75 x$ ddoses $=225 \mathrm{~g}=450$ (L.E.) $/$ feddan

- One feddan $=900$ vines

- Price/1 kg from Yield = 2.5 (L .E.) 


\section{Discussion}

The increment in yield per vine and chemical characteristics of the berries, could be attribute to enhancing effect on berry weight as result of enhancing the nutritional status of the vines (Table 3 ) and enhancing leaf surface area and total chlorophyll in leaves (Table 2) as result using amino acids and vitamins.

The promoting effect of amino acids on growth and fruiting of Flame seedless grapevines might be attributed to their positive action on protecting plants from oxidative stress, enhancing the biosynthesis of proteins through polymerization of amino acids, ethylene, $\mathrm{GA}_{3}$, IAA, cyokinins, plant pigments, and organic foods (Davies, 1982).

Arginine plays an important role in cell division, the healing of wounds, removing ammonia from the body, immune function, and release of hormone (Stanislavov and Nikolova, 2003). Also, Arginine is an important and unique amino acid in plants. It serves not only as an important nitrogen reserve and recycling, but also as a precursor of the biosynthesis of polyamines, nitric oxide and so on. Polyamines and nitric oxide are important messengers involved in almost all physiological and biochemical processes including regulation of DNA replication, transcription of gens, cell division, fruit ripping, leaf senescence, growth, development, and adaptation of plants to environmental disturbances. (Yang and Gao, 2007).

Glutamic acid is an essential amino acid that counteracts the adverse effects of all stresses around the trees as well as its effect on forming proteins and other related compounds (Yagodin, 1990).

Methonin as amino acid plays a significant role in plant metabolism through its metabolite, S-adenosyl - methonin (SAM), methonin controls the levels of several key metabolites such as ethylene, polyamines and biotin. SAM is also the primary methyl group donor that regulates different processes in plants such as cell wall and chlorophyll synthesis (Rachel and Hacahm, 1998).

The positive action of vitamins on growth and fruiting of Flame seedless grapevines might be attributed to their essential role on protecting the plant cells from senescence and various disorders as well as enhancing cell division, the biosynthesis of natural hormones such as IAA and ethylene, nutrient and water uptake, photosynthesis, building of plant pigments and proteins, amino acids and plant metabolism. These important functions of vitamins surely reflected on enhancing growth and vine nutritional status in favor of enhancing yield and fruit quality (Samiulla et al., 1988).

Vitamin B1 (Thiamin) is a necessary ingredient for biosynthesis of the coenzyme thiamin pyrophosphate. It plays an impotent role in carbohydrate

Egypt. J. Hort. Vol. 43, No. 1 (2016) 
metabolism .It is an essential nutrient for plants, it is synthesized in the leaves and in transported to the root where it controls the growth. (Kawasaki, 1992).

Vitamin $\mathrm{B}_{2}$ (Riboflavin) occurs generally in plant tissues, but only a small amount appears to be free while the main part as coenzymes, flavin monoucleotide and flavin adenine, dinucleotide. It has a pronounced role in photosynthesis (Mer, 1957).

These results regarding the beneficial effects of amino acid and vitamins on growth, vines nutritional status, yield as well as physical and chemical characteristics of the berries are in harmony with those obtained by (Melouk, 2007, Megawer \& Abd El-Hameed 2009, Sabry Gehan, 2009, Fayed, 2010, Ahmed et al., 2011, Madian \& Refaai, 2011, khan et al., 2012, El-Sayed, 2013, Abdelaal et al., 2014, Al-khawaga 2014, Faissal et al., 2014, Al- Wasfy, 2014 and Faissal et al., 2015).

\section{Conclusion}

The best results with regard to vegetative growth, yield, fruit quality and net profit /feddan of Flame seedless grapevines were obtained when the vines were spraying with Argenine at a rate (500 ppm) plus vitamin B2 at a rate (250) ppm for three times at growth start (when shoots length reached about $40-50 \mathrm{~cm}$ ), after fruit and 2 weeks after fruit set.

\section{References}

A.O.A.C. (1980) "Association of Official Analytical Chemists", $14^{\text {th }}$ ed., published by A.O.A.C., Washington D.C., USA.

Abd El-Aal, A.H.M., El- Masry, S.E.M.A., Abd El-Wahab, M.A. and Abd El- Latief, M.M.H. (2014) Relation of yield and berries quality of Thompson seedless grapevines to foliar application of some vitamins. World Rural Observations, 6 (2), $58-64$.

Ahmed, F.F., Ibrahiem, A.A., Mansour, A.E.M., Shaaban, E.A. and El-Shamaa, M.S. (2011) Response of Thompson seedless grapevines to application of some amino acids enriched with nutrients as well as organic and biofertilization. Res. J. Agric. Bio. Sci., 7 (2), $282-286$.

Al-Khawaga, A.S. (2014) Impact of vitamins B and C, Glutamic acid and silicon on fruiting of Superior grapevines. World Rural Observations, 6 (4), 57-62.

Al-Wasfy, M.M.M. (2014) The synergistic effects of using silicon with some vitamins on growth and fruiting of Flame seedless grapevines. Stem Cell, 5 (1), 8 -13. 
Cottenie, A., Verloo, M., Kiekens, L., Relgho, G. and Camerlynuck, W. (1982) "Chemical Analysis of Plant and Soil". Lab. of analytical and Agro chemistry State Univ. Gent, Belgium

Davies, D.D. (1982) Physiological aspects of protein turn over. Encycl. Plant Physiol., 45, 481- 487.

El-Sayed, M.E.A. (2013) Improving fruit quality and marketing of "Crimson Seedless" grape using some preharvest treatments J. Hort. Sci. \& Ornamen. Plants, 5 (3), 218-226.

Faissal, F.A., Abd El-Aal, A.H.M., El-Masry, S.E.M.A. and Farag, W.B.M.M. (2014) Response of Superior grapevines to foliar application of some micronutrients, calcium, amino acids and salicylic acid. World Rural Observations, 6 (3), 57-64.

Faissal, F.A., Abd El-Aziz, F.H., Gobara A.A., El- Mamlouk, E.A.H. and Hashem, M.H.A. (2015) Behaviour of Superior grapevines to foliar application of some vitamins and amino acids. World Rural Observations, 7 (1), 100-107.

Fayed, T.A. (2010) Effect of some antioxidants on growth, yield and bunch characters of Thompson seedless grapevines. Amer. Eurasian J. Agric. Environ. Sci., 8 (3), 322-328.

Husia, C.L., Luh, B.S. and Chichester, C.D. (1965) Anthocyanin in free stone peach. $J$. Food Sci., 30, 5-12.

Khan, A.S., Bilal, A., Jaskani, M.J., Rashid, A. and Malik, A.U. (2012) Foliar application of mixture of amino acids and seaweed extract improve growth and physicochemical properties of grapes. Int. J. Agric. Biol., 14 (3), 383 - 388 .

Kawasaki, T. (1992) "Modern Chromatographic Analysis of Vitamins", $2^{\text {nd }}$ ed., Vol. 60, New York Marcel, Dekker Inc., pp. 319-354.

Mackinny, G. (1941) Absorption of light by chlorophyll soluation. J. Bio. Chem., 140, $315-322$

Madian, A.M. and Refaai, M.M. (2011) The synergistic effects of using B vitamins with the two amino acids tryptophan and methionene in Thompson seedless grapevines. Minia J. Agric. Res. \& Develop., 3 (3), 445-455.

Malick, C.P. and Singh, M.B. (1980) In Plant Enzynology and Hist Enzynology Khlyani Publishers, New Delhi, 286 p.

Megawer, M.A. and Abd El-Hameed, H.M. (2009) Response of Thompson seedless grapevines to spraying some vitamins. Minia J. of Agric. Res. \& Develop., 29 (3), 371-389.

Melouk, A.M. (2007) Effect of Phenylalanine, Puterscine and Spermidine on yield berry quality Thompson seedless grapevine, J. Agric. Sci. Mansoura Univ., 32 (2), 1245-1254.

Egypt. J. Hort. Vol. 43, No. 1 (2016) 
Mer, C.L.A. (1957) Re- examination of the supposed effect of riboflavin on growth. Plant physiology, 32, $175-185$.

Montero, F.J., De Juan, J.A., Cuesta, A. and Brasa, A. (2000) Non-destructive methods to estimated leaf area in (Vitis vinifera L.). Hort. Sci., 35, 696 - 698.

Oretili, J.J. (1987) Exogenous application of vitamins as regulators for growth and, development of plants. Pflanzenrahr Bpdenk, 150, 375-391.

Rai, V.K. (2002) Role of amino acids in plant responses to stress, Biol. Plant, 45, 471-478.

Rachel, A. and Hacahm, Y. (1998) Methionine Metabolism in Plants: current understanding of the factors regulating its metabolism, pp. 61-86.

Robinson, F.A. (1973) "Vitamins Phytochemistry", Vol. III: 195-198. Lawrence P. Miller (Ed.). Van. No strand Rinhold Comp. New York, pp. 50-60.

Sabry Gehan, G.H., Rizk-Alla, M.S. and Abd El-Wahab M.A. (2009) Influence of effective micro-organisms, seaweed extract and amino acids application on growth, yield and berry quality of Red Globe grapevines, J. Agric. Sci. Mansoura Univ., 34 (6), 6617-6637.

Sadasivam, S. and Manickam, A. (1996) "Biochemical Methods", $2^{\text {nd }}$ ed., New Age International, India.

Samiullah, S.A., Ansori, M.M. and Afridi, R.K. (1988) B- Vitamins in relation to crop productivity, Indian Rev. Life Sci., 8, 51-74.

Selim, H.H.A., Fayek, M.A. and Sweidan, A.M. (1978) Reproduction of bircher apple cultivar by layering. Ann. Agric. Sci. Moshtohor, 9, 157-166.

Snedecor, G.W. and Cochran, W.G. (1980) "Statistical Methods". $7^{\text {th }}$ ed., The Iowa State Univ. Press. Ames. , Iowa, U.S.A., 593 p.

Stanislavov, R. and Nikolova, V. (2003) Treatment of erectile dysfunction with pycnogenol and L-argenine. Journal of Sex and Marital Therapy, 29 (3), 207 - 213.

Yagodin, B.A. (1990) "Agricultural Chemistry", Mir Publishers Moscow, pp. 278- 281.

Yang, H.Q. and Gao, H.J. (2007) Hysiological function of Argenine and its metabolites in plants. Zhi Wu Sheng Li Yu Fen Zi Sheng Wu Xue Xue Bao, 33 (1), 1-8.

(Received 15/ 2/ 2016;

accepted 15/5/2016) 


\section{استخدام بعض الأحماض الأمينية والفيتامينات لتحسين النمو والصفات الطبيعية و الكيمائية لعنب القليم سيدلن والفينات لفين}

بسام السبد عبد المقصود بلال ، مسعد عوض القناوى وماهر خيرى يواقيم

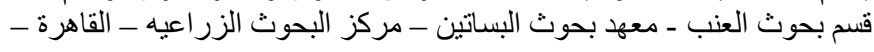

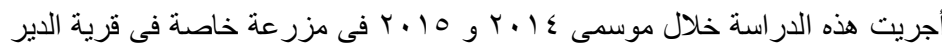

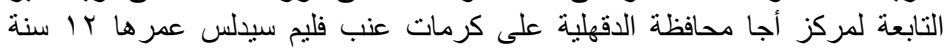

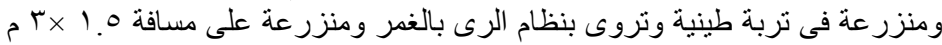

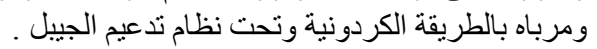

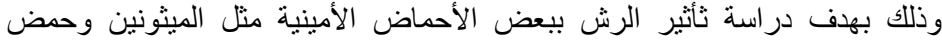

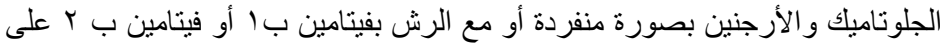

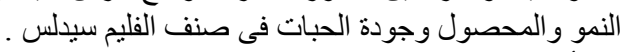

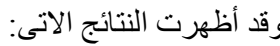

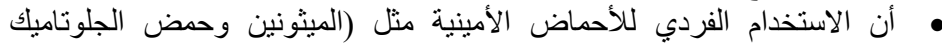

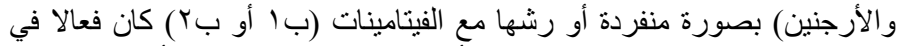

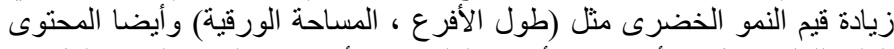

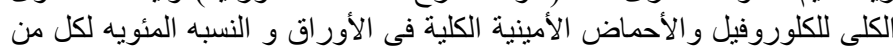

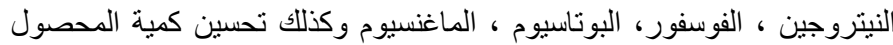

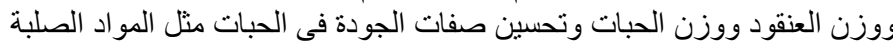

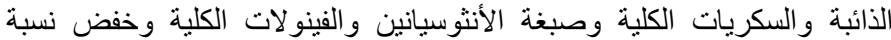

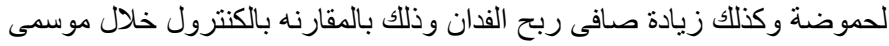
الار اسة.

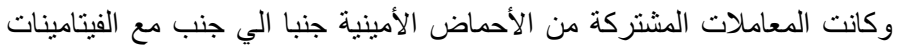

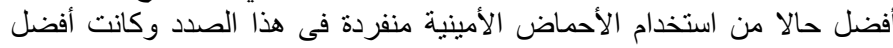

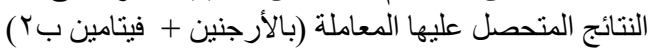

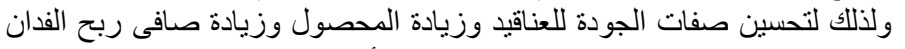

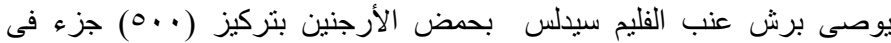

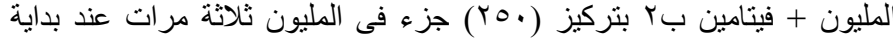
النمو الخضرى و عند تمام العقد وبعد العقد باسبو عين. 